\title{
Broom snakeweed responses to drought: II. Root growth, carbon allocation, and mor- tality
}

\author{
CHANGGUI WAN, RONALD E. SOSEBEE, AND BOBBY L. MCMICHAEL
}

\begin{abstract}
Authors are postdoctoral research associate and professor, Department of Range and Wildlife Management, Texas Tech University, Lubbock 79409; and plant physiologist, USDA-ARS, Cropping Systems Research Laboratory, Lubbock, Texsas.
\end{abstract}

\begin{abstract}
The effects of soil water deficit on root growth, carbon allocation, and plant mortality of broom snakeweed (Gutierrezia sarothrae (Pursh) Britt and Rusby) were studied during the springsummer growing season in plants subjected to different soil water regimes. As soil water deficit developed, root length density decreased, indicating that water deficit reduced root proliferation. Root/shoot ratio remained unchanged $(p>0.05)$ as soil water potential decreased from $-0.023 \mathrm{MPa}$ to $-2 \mathrm{MPa}$; but it became higher $(p<0.05)$ in extremely stressed plants $(-3.4 \mathrm{MPa})$, indicating that root growth was favored over shoot growth. Root length density was more closely correlated with green tissue dry weight/stem dry weight ratio $(r=0.82, p<0.0001)$ than with root/shoot ratio $(r=0.52, p<0.05)$. This suggests that (1) expansion of photosynthetic area was more sensitive than stem growth to water deficit and (2) carbon allocation within the shoot was more sensitive to water deficit than allocation between root and shoot. Plants died when gravimetric soil water decreased to around $0.03 \mathrm{~g} \mathrm{~g}^{-1}$ (equivalent to a soil water potential of $-7.5 \mathrm{MPa}$ ). The leaf relative water content just before death was about 0.50 . Soil water content in the top 20 or $30 \mathrm{~cm}$ of the profile is the single most important factor determining mortality of the snakeweed plant and can be used in making decisions in snakeweed control programs.
\end{abstract}

Key Words: rangeland xerophytes, water relations, root/shoot ratio, root length density, drought damage

Plant adaptation in arid and semiarid area is often associated with changes in root growth relative to shoot growth (Fernandez and Caldwell 1975, Sharp and Davies 1979, Morgan 1984). Morgan (1984) stated that in the absence of osmoregulation, a wellobserved adaptational response is a reduction in shoot growth relative to root growth. Wan et al. (1993a) have found osmotic adjustment in field-grown broom snakeweed (Gutierrezia sarothrae (Pursh) Britt and Rusby) subject to drought, but not in the greenhouse-grown plants which adapted to drought through increased apoplastic water fraction. We do not know if increased root/shoot ratio contributes to drought adaptive mechanisms in broom snakeweed. Osman and Pieper (1988) indicates that root/shoot ratio in broom snakeweed seedlings grown in the field was nearly constant in early summer and decreased slightly in late summer. A fairly constant root/shoot ratio in broom snakeweed seedlings suggests that the plant can maintain a proper balance in

\footnotetext{
Research was funded by USDA-ARS and the Institute for Plant Stress Research of Texas Tech University (Project No. 6208-22230-00I-01S). Authors wish to thank 2 anonymous reviewers for their contribution to the revision of the initial manuscript.

Contribution T-9-630 of the College of Agricultural Sciences, Texas Tech University. The senior author is visiting scientist of Gansu Grassland Ecological Research Institute, Lanzhou, China.

Manuscript accepted 21 Dec. 1992.
}

carbon investment between water acquisition and consumption under increasing drought. But since soil moisture was not monitored in this study, the effect of soil drying on root growth was not elucidated. It may also be possible that the modification in carbon allocation within shoots plays a significant role in the endurance of the stressed plants (Tyree and Sperry 1989).

The objectives of this research were to test: (1) the effects of various water deficit levels on root length and biomass of snakeweed; (2) the effects of various water deficit levels on carbon allocation pattern; and (3) the threshold water deficit level at which quiescence occurs and perennial stems die.

\section{Materials and Methods}

The experiment layout and methods for soil and plant water potential measurements were similar to those of Wan et al. (1993b). A total of 120 broom snakeweed plants were subject to 5 irrigation (irr.) treatments: well-watered (WW, $100 \%$ irr.), slightly stressed (SS, $50 \%$ irr.), moderately stressed (MS, $25 \%$ irr.), severely stressed (SVS, $12.5 \%$ irr.), and extremely stressed (ES, no irr.). Soil volumetric water content in the field was measured with the TDR technique (Wan et al. 1993b). Stainless steel rods $0.64 \mathrm{~cm}$ in diameter were cut into $20-, 40-$, and $60-\mathrm{cm}$ lengths and pairs of rods were inserted vertically into the soil at a parallel distance of $5 \mathrm{~cm}$. Four replications were installed at the study site. Mortality of broom snakeweed plants was monitored during the experiment and was related to soil water availability. Field observation of plant mortality was also made to verify the results from the pot study.

Above- and below-ground biomass, green tissue (green leaf plus green stem) area, and total root length were measured at the end of the vegetative stage ( 30 June). Green tissue area was measured with a Li-3100 area meter. The root system was sorted as white roots and brown-colored suberized roots. Biomass of various plant parts was measured as oven-dry weight ( $70^{\circ} \mathrm{C}$ for 24 hours), and root length was measured with a Comair optical scanner (Hawker Dehavilland Inc., Australia). Root length density (RLD) was calculated as root length per unit soil volume ( $\mathrm{cm}$ root $\mathrm{cm}^{-3}$ soil).

The experiment consisted of a complete randomized design with 5 treatments. Three plants per treatment were harvested to obtain the above- and belowground biomass means. The treatment means were separated with Fisher's least significant difference at $p<0.05$. Correlations were made between various parameters using the Pearson correlation procedure.

\section{Results and Discussion}

Root length density was highest in the well-watered treatment $(-0.02 \mathrm{MPa})$, followed by the slightly $(-0.2 \mathrm{MPa})$ and moderately stressed $(-1.1 \mathrm{MPa})$ treatments, and lowest in the severely $(-2$ 
Table 1. Root length, root dry weight, root length density (RLD), and root/shoot ratio in broom snakeweed subject to 5 treatments (Trt) sampled at the end of the vegetative stage in late June.

\begin{tabular}{|c|c|c|c|c|c|c|}
\hline \multirow[b]{2}{*}{ Trt } & \multicolumn{2}{|c|}{ Root length } & \multicolumn{2}{|c|}{ Root weight } & \multirow[b]{2}{*}{ RLD } & \multirow[b]{2}{*}{$\begin{array}{l}\text { Root/ } \\
\text { shoot }\end{array}$} \\
\hline & $\begin{array}{l}\text { White } \\
\text { root }\end{array}$ & $\begin{array}{c}\text { Suberized } \\
\text { root }\end{array}$ & $\begin{array}{l}\text { White } \\
\text { root }\end{array}$ & $\begin{array}{l}\text { Suberized } \\
\text { root }\end{array}$ & & \\
\hline $\begin{array}{r}\text { WW' } \\
\text { SD }\end{array}$ & $\begin{array}{c}\ldots . .-1 \\
330.5 \mathrm{a} \\
54.1\end{array}$ & $\begin{array}{l}\text { m) }-\ldots . \\
2.57 \mathrm{ab} \\
2.18\end{array}$ & $\begin{array}{l}-\ldots .-1 \\
3.31 \mathrm{a} \\
1.12\end{array}$ & $\begin{array}{l}\text { g) }-\ldots \\
2.67 \mathrm{ab} \\
0.27\end{array}$ & $\begin{array}{c}-\left(\mathrm{cm} \mathrm{cm}^{-3}\right)- \\
1.75 \mathrm{a} \\
0.29\end{array}$ & $\begin{array}{l}0.23 \mathrm{a} \\
0.03\end{array}$ \\
\hline $\begin{array}{l}\text { SS } \\
\text { SD }\end{array}$ & $\begin{array}{c}172.6 \mathrm{~b} \\
8.8\end{array}$ & $\begin{array}{l}3.05 \mathrm{a} \\
1.36\end{array}$ & $\begin{array}{l}2.08 \mathrm{~b} \\
0.25\end{array}$ & $\begin{array}{l}3.20 \mathrm{a} \\
0.50\end{array}$ & $\begin{array}{l}0.91 \mathrm{~b} \\
0.05\end{array}$ & $\begin{array}{l}0.25 \mathrm{a} \\
0.03\end{array}$ \\
\hline $\begin{array}{l}\text { MS } \\
\text { SD }\end{array}$ & $\begin{array}{c}170.2 \mathrm{~b} \\
11.4\end{array}$ & $\begin{array}{l}0.54 \mathrm{ab} \\
0.17\end{array}$ & $\begin{array}{l}1.46 b c \\
0.16\end{array}$ & $\begin{array}{l}2.49 \mathrm{ab} \\
0.23\end{array}$ & $\begin{array}{l}0.91 \mathrm{~b} \\
0.06\end{array}$ & $\begin{array}{l}0.36 \mathrm{a} \\
0.02\end{array}$ \\
\hline $\begin{array}{c}\text { SVS } \\
\text { SD }\end{array}$ & $\begin{array}{l}82.0 \mathrm{c} \\
33.1\end{array}$ & $\begin{array}{l}0.48 \mathrm{ab} \\
0.25\end{array}$ & $\begin{array}{l}1.03 b c \\
0.17\end{array}$ & $\begin{array}{l}1.82 \mathrm{bc} \\
0.44\end{array}$ & $\begin{array}{l}0.43 \mathrm{c} \\
0.18\end{array}$ & $\begin{array}{l}0.29 a \\
0.04\end{array}$ \\
\hline $\begin{array}{l}\text { ES } \\
\text { SD }\end{array}$ & $\begin{array}{l}42.9 \mathrm{c} \\
25.6\end{array}$ & $\begin{array}{l}0.39 \mathrm{~b} \\
0.07\end{array}$ & $\begin{array}{l}0.56 \mathrm{c} \\
0.19\end{array}$ & $\begin{array}{l}1.24 c \\
0.59\end{array}$ & $\begin{array}{l}0.23 \mathrm{c} \\
0.14\end{array}$ & $\begin{array}{l}0.56 \mathrm{~b} \\
0.17\end{array}$ \\
\hline
\end{tabular}

IWW-well watered, SS-slightly stressed, MS-moderately stressed, SVS-severely stressed, ES-extremely stressed, $S D$-standard deviation, $n=3$ for each treatment. Means followed by the same letter are not different at $p<0.05$ level.

and extremely stressed $(-3.4 \mathrm{MPa}$ ) treatments (Table 1 and Wan et al. 1993b). Sharp and Davies (1979) found absolute root growth increased in maize seedlings subjected to an intermediate degree of water deficit. In the present study, white root length was lower under increased water stress. The root/shoot ratio in the extremely stressed treatment was significantly greater than in any other treatment $(p<0.05$, Table 1); no difference $(P>0.05)$ was found among the other 4 treatments. Because the extremely stressed treatment did not receive any irrigation during mid April to late June, the plants exploited the soil by proportionately more root growth. The root/shoot ratio was significantly correlated with suberized root/ white root ratio $(r=0.67, p<0.01)$ (Table 2), indicating an increased proportion of suberized root biomass under soil water deficit. Increased root suberization can prevent water
Table 3. Green tissue area (GTA), Green tissue dry weight (GTDW), stem dry weight (SDW), GTDW/SDW, Green tissue area/biomass (GTA/DW) in broom snakeweed subject to 5 treatments (Trt) sampled at the end of the vegetative stage in late June, 1991.

\begin{tabular}{|c|c|c|c|c|c|}
\hline Trt & GTA & GTDW & SDW & $\begin{array}{l}\text { GTDW/ } \\
\text { SDW }\end{array}$ & $\begin{array}{c}\text { GTA/ } \\
\text { DW }\end{array}$ \\
\hline $\begin{array}{c}\text { WW } \\
\text { SD }\end{array}$ & $\begin{array}{c}\left(\mathrm{cm}^{2}\right) \\
590.2 \mathrm{a} \\
17.7\end{array}$ & $\begin{array}{c}(\mathrm{g}) \\
24.05 \mathrm{a} \\
1.29\end{array}$ & $\begin{array}{l}\quad(g) \\
1.42 \mathrm{a} \\
0.41\end{array}$ & $\begin{array}{c}18.42 \mathrm{a} \\
5.53\end{array}$ & $\begin{array}{c}\left(\mathrm{cm}^{2} / \mathrm{g}\right) \\
23.21 \mathrm{a} \\
0.79\end{array}$ \\
\hline $\begin{array}{l}\text { SS } \\
\text { SD }\end{array}$ & $\begin{array}{c}456.8 \mathrm{~b} \\
48.4\end{array}$ & $\begin{array}{c}18.40 \mathrm{~b} \\
1.77\end{array}$ & $\begin{array}{l}2.71 \mathrm{abc} \\
0.77\end{array}$ & $\begin{array}{l}7.21 \mathrm{~b} \\
1.62\end{array}$ & $\begin{array}{c}21.69 \mathrm{~b} \\
1.01\end{array}$ \\
\hline $\begin{array}{l}\text { MS } \\
\text { SD }\end{array}$ & $\begin{array}{c}188.9 \mathrm{c} \\
17.4\end{array}$ & $\begin{array}{l}8.11 \mathrm{c} \\
0.73\end{array}$ & $\begin{array}{l}2.89 \mathrm{ab} \\
0.96\end{array}$ & $\begin{array}{l}3.13 b c \\
1.08\end{array}$ & $\begin{array}{c}17.29 \mathrm{~b} \\
2.25\end{array}$ \\
\hline $\begin{array}{c}\text { SVS } \\
\text { SD }\end{array}$ & $\begin{array}{c}150.9 \mathrm{c} \\
22.5\end{array}$ & $\begin{array}{l}6.10 \mathrm{c} \\
0.98\end{array}$ & $\begin{array}{l}3.85 b c \\
0.29\end{array}$ & $\begin{array}{l}1.58 b c \\
0.17\end{array}$ & $\begin{array}{c}15.11 \mathrm{c} \\
0.48\end{array}$ \\
\hline $\begin{array}{l}\text { ES } \\
\text { SD }\end{array}$ & $\begin{array}{c}37.9 \mathrm{~d} \\
1.0\end{array}$ & $\begin{array}{l}1.68 \mathrm{~d} \\
0.13\end{array}$ & $\begin{array}{l}1.54 \mathrm{ab} \\
0.43\end{array}$ & $\begin{array}{l}1.18 \mathrm{c} \\
0.35\end{array}$ & $\begin{array}{c}11.88 \mathrm{c} \\
1.42\end{array}$ \\
\hline
\end{tabular}

$\mathrm{n}=3$ for each treatment, $S D$-standard deviation. Means followed by the same letter are not different $(p>0.05)$

movement from the root to the very dry soil (Nobel and Sanderson 1984).

Green tissue area/unit of biomass was ordered according to $\mathrm{WW}=\mathrm{SS}>\mathrm{MS}=\mathrm{SVS}>\mathrm{ES}(p<0.05)$ (Table 3$)$. The green tissue/ woody stem ratio declined linearly with increasing soil water deficit $\left(r^{2}=0.99\right.$, Fig. 1). In the severely and extremely stressed treatments as compared to other treatments, this ratio dropped to less than 1.6 , suggesting that a greater proportion of exported carbon was invested in stems and a smaller proportion was partitioned into expansion of photosynthetic area. It could also mean a loss of leaves as shown by Wan et al. (1993b). But, stem dry weight was over 2 -fold greater $(p<0.05$, Table 3$)$ in the severely stressed treatment than in the well-watered treatment, indicating more carbon was invested in the stems under severe stress. DePuit and Caldwell (1975) found that green leaf/green stem ratio of snakeweed in the cold desert declined from spring to summer. Apparently, the car-

Table 2. Correlation coefficients between the parameters.

\begin{tabular}{|c|c|c|c|c|c|c|c|c|c|c|c|}
\hline$\overline{\text { GTA }^{1}}$ & GTDW & SDW & $\begin{array}{l}\text { GTDW: } \\
\text { SDW }\end{array}$ & $\overline{W R L}$ & SRL & WRW & SRW & $S / W$ & RLD & $R / S$ & \\
\hline \multirow[t]{10}{*}{$\begin{array}{l}1.0 \\
0.0\end{array}$} & $\begin{array}{l}.999 \\
.001\end{array}$ & $\begin{array}{l}-.21 \\
.448\end{array}$ & $\begin{array}{l}.837 \\
.000\end{array}$ & $\begin{array}{l}.867 \\
.000\end{array}$ & $\begin{array}{l}.668 \\
.006\end{array}$ & $\begin{array}{l}.864 \\
.000\end{array}$ & $\begin{array}{l}.69 \\
.004\end{array}$ & $\begin{array}{l}-.51 \\
.052\end{array}$ & $\begin{array}{l}.867 \\
.000\end{array}$ & $\begin{array}{l}-.65 \\
.009\end{array}$ & GTA \\
\hline & $\begin{array}{l}1.0 \\
0.0\end{array}$ & $\begin{array}{r}-.21 \\
.443\end{array}$ & $\begin{array}{l}.843 \\
.000\end{array}$ & $\begin{array}{l}.881 \\
.000\end{array}$ & $\begin{array}{l}.659 \\
.007\end{array}$ & $\begin{array}{l}.879 \\
.000\end{array}$ & $\begin{array}{l}.699 \\
.004\end{array}$ & $\begin{array}{l}-.51 \\
.052\end{array}$ & $\begin{array}{l}.880 \\
.000\end{array}$ & $\begin{array}{l}-.64 \\
.010\end{array}$ & GTDW \\
\hline & & $\begin{array}{l}1.0 \\
0.0\end{array}$ & $\begin{array}{l}-.52 \\
.046\end{array}$ & $\begin{array}{l}-.31 \\
.263\end{array}$ & $\begin{array}{r}-.12 \\
.668\end{array}$ & $\begin{array}{l}-.30 \\
.272\end{array}$ & $\begin{array}{l}.134 \\
.633\end{array}$ & $\begin{array}{l}.123 \\
.662\end{array}$ & $\begin{array}{r}-.29 \\
.289\end{array}$ & $\begin{array}{l}-. .34 \\
.213\end{array}$ & SDW \\
\hline & & & $\begin{array}{l}1.0 \\
0.0\end{array}$ & $\begin{array}{l}.825 \\
.000\end{array}$ & $\begin{array}{l}.337 \\
.219\end{array}$ & $\begin{array}{l}.879 \\
.000\end{array}$ & $\begin{array}{l}.385 \\
.157\end{array}$ & $\begin{array}{l}-.49 \\
.006\end{array}$ & $\begin{array}{l}.822 \\
.000\end{array}$ & $\begin{array}{l}-.44 \\
.102\end{array}$ & $\begin{array}{l}\text { GTDW } \\
\text { :SDW }\end{array}$ \\
\hline & & & & $\begin{array}{l}1.0 \\
0.0\end{array}$ & $\begin{array}{l}.535 \\
.039\end{array}$ & $\begin{array}{l}.918 \\
.000\end{array}$ & $\begin{array}{l}.531 \\
.042\end{array}$ & $\begin{array}{l}-.65 \\
.009\end{array}$ & $\begin{array}{l}.989 \\
.000\end{array}$ & $\begin{array}{l}-.53 \\
.044\end{array}$ & WRL \\
\hline & & & & & $\begin{array}{l}1.0 \\
0.0\end{array}$ & $\begin{array}{l}.511 \\
.051\end{array}$ & $\begin{array}{l}.507 \\
.054\end{array}$ & $\begin{array}{l}-.30 \\
.269\end{array}$ & $\begin{array}{l}.542 \\
.037\end{array}$ & $\begin{array}{l}-.35 \\
.194\end{array}$ & SRL \\
\hline & & & & & & $\begin{array}{l}1.0 \\
0.0\end{array}$ & $\begin{array}{l}.480 \\
.069\end{array}$ & $\begin{array}{l}-.64 \\
.01\end{array}$ & $\begin{array}{l}.909 \\
.000\end{array}$ & $\begin{array}{l}-.51 \\
.050\end{array}$ & WRW \\
\hline & & & & & & & $\begin{array}{l}1.0 \\
0.0\end{array}$ & $\begin{array}{l}.007 \\
.979\end{array}$ & $\begin{array}{l}.562 \\
.029\end{array}$ & $\begin{array}{l}-.38 \\
.155\end{array}$ & SRW \\
\hline & & & & & & & & $\begin{array}{l}1.0 \\
0.0\end{array}$ & $\begin{array}{r}-.60 \\
.017\end{array}$ & $\begin{array}{l}.667 \\
.006\end{array}$ & $\mathbf{S} / \mathbf{W}$ \\
\hline & & & & & & & & & $\begin{array}{l}1.0 \\
0.0\end{array}$ & $\begin{array}{l}-.52 \\
.049\end{array}$ & RLD \\
\hline
\end{tabular}

IGTA-green tissue area, GTDW-green tissue dry weight, SDW-stem dry weight, WRL-white root length, SRL-suberized root length, WRW-white root weight, SR W-suberized root weight, $S$ /W-suberized root weight/ white root weight, $R L D$-root length density, $R / S$-root/shoot ratio. (The second number in each cell is the $p$ value). 
bon allocation pattern in the shoot was more sensitive to drought than the root/shoot ratio.

Sperry and Tyree (1990) indicated that xylem embolism occurs daily in droughted plants at threshold plant water potentials ranging from $-2.0 \mathrm{MPa}$ in balsam fir (Abies balsamea (L.) Mill.) to -3.5 $\mathrm{MPa}$ in eastern redcedar (Juniperus virginiana $\mathrm{L}$.). In the present study, plant water potentials in the moderately, severely, and extremely stressed treatments were lower (Wan et al. 1993b) than the threshold values for the conifers species including the drought tolerant eastern redcedar, which is least vulnerable to caviation (Tyree and Ewers 1991). Less stomatal control over water loss and low soil water potentials in these treatments (Wan et al. 1993b) also could cause runaway embolism (Tyree and Ewers 1991). Individual branches of the droughted broom snakeweed plants often showed signs of stress damage (losing green color), while other branches were not affected. This dead-branch leaf loss is consistent with, and perhaps caused by, some loss of xylem elements (Tyree and Sperry 1989). This characteristic may be advantageous to the plant survival because it reduces whole plant transpiration and prevents the main branch from cavitation (Zimmerman 1983). Jones and Sutherland (1991) pointed out that the stressed plant could invest additional carbohydrate to build excess conducting tissue as a buffer against some loss of xylem vessels. This may explain the increased carbon investment in stems in the stressed broom snakeweed plant.

Root length density, an index of water uptake capacity, is more closely correlated with the green tissue/stem ratio $(r=0.82$, $p<0.0001, \mathrm{n}=15$, Table 2$)$ than with the root/ shoot ratio $(r=-0.52$, $p<0.049, \mathrm{n}=15$ ). This seems to indicate that expansion of photosynthetic area is more sensitive to water deficit than stem growth and modification of carbon allocation within the shoot is more significant to the plant than changes in root/shoot ratio in response to soil drying. In the moderately, severely, and extremely stressed treatments when soil water availability is very low $(<-1.1$ $\mathrm{MPa}$, Wan et al. 1993b), additional carbon investment in the roots does little to improve the plant water balance. Consequently, less carbon will be invested in construction of transpiring area, resulting in reduced water consumption. More carbon may be allocated to the conduits through more rapid primary (and secondary) wall growth, resulting in smaller pit-membrane pores which are less vulnerable to cavitation (Tyree and Sperry 1989). Snakeweed has photosynthetic stems that can account for up to $20 \%$ of the total carbon fixation during drought (DePuit and Caldwell 1975). Increased carbon allocation to the self-supportive stems reduces surface area/volume ratio; therefore, this can be a very important drought-adapted strategy.

From April until mid September, $80 \%$ of plants in the extremely stressed treatment and $8 \%$ of plants in the severely stressed treatment died $(n=24)$. Before the plants died, we repeatedly measured volumetric soil water content of about $0.044 \mathrm{~cm}^{3} \mathrm{~cm}^{-3}$, which is equivalent to a gravimetric water content of $0.03 \mathrm{~g} \mathrm{~g}^{-1}$ and water potential of $-7.5 \mathrm{MPa}$. Similar observations were made by Courtney (1984), who found that a major "die-off" of broom snakeweed plants occurred when water content in a sandy loam soil dropped to $0.03 \mathrm{~g} \mathrm{~g}^{-3}$ under field conditions.

In the field, when water content in the top $20-\mathrm{cm}$ of soil decreased to $0.065 \mathrm{~cm}^{3} \mathrm{~cm}^{-3}\left(0.043 \mathrm{~g} \mathrm{~g}^{-1}\right.$, Fig. 2) in mid July and early August, death of some snakeweed plants was also noted. The water content of the topsoil in the field was similar to that in the severely stressed treatment $\left(0.067 \mathrm{~cm}^{3} \mathrm{~cm}^{-3},-2 \mathrm{MPa}\right)$ in which $8 \%$ of plants died. It appears that broom snakeweed is sensitive to changes in soil water content in the topsoil, where most of its root system is located (DePuit and Caldwell 1975). When exposed to a soil water potential of $-2 \mathrm{MPa}$ for some period of time, some mortality will occur. However, the major die-off will not take place

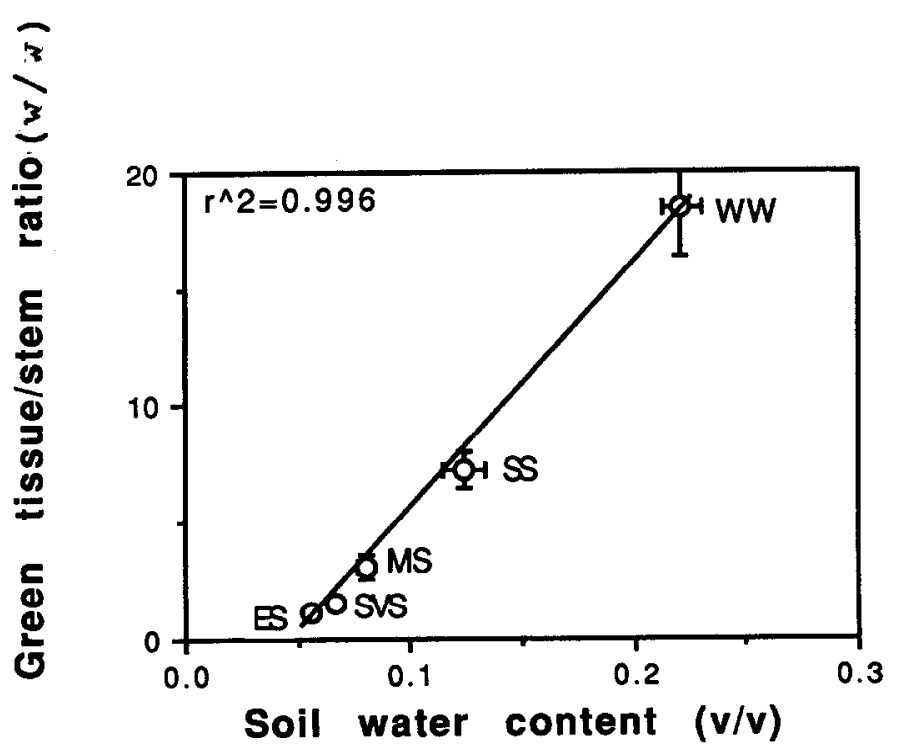

Fig. 1. Green tissue dry weight/stem dry weight ratio as influenced by soil water regimes for each treatment. Each data point is the average of 3 observations.

until soil water potential is further reduced to $-7.5 \mathrm{MPa}$ (or water content of $0.03 \mathrm{~g} \mathrm{~g}^{-1}$ in the fine sandy loam soil). Leaf relative water content (RWC) was often reduced to $50 \%( \pm 2.8 \% \mathrm{SE}, \mathrm{n}=6)$ before the plants showed signs of dying (leaves turn brown). This is comparable to the findings of Hinckley et al. (1983) that revealed that the relative water content at which irreversible cell damage occurred in 6 shrub species ranged from $45.7 \%$ to $62.7 \%$. Plant water potential in the extremely stressed treatment was about -8 $\mathrm{MPa}$, which may make the plant operate on the verge of catastrophic xylem dysfunction and may explain much of the plant death.

The soil volume occupied by the root system is different in the pot- versus field-grown plants, as is the total water availability in the rooting zone. It is also possible that soil temperature can vary from the pot to field conditions. Despite these differences, the

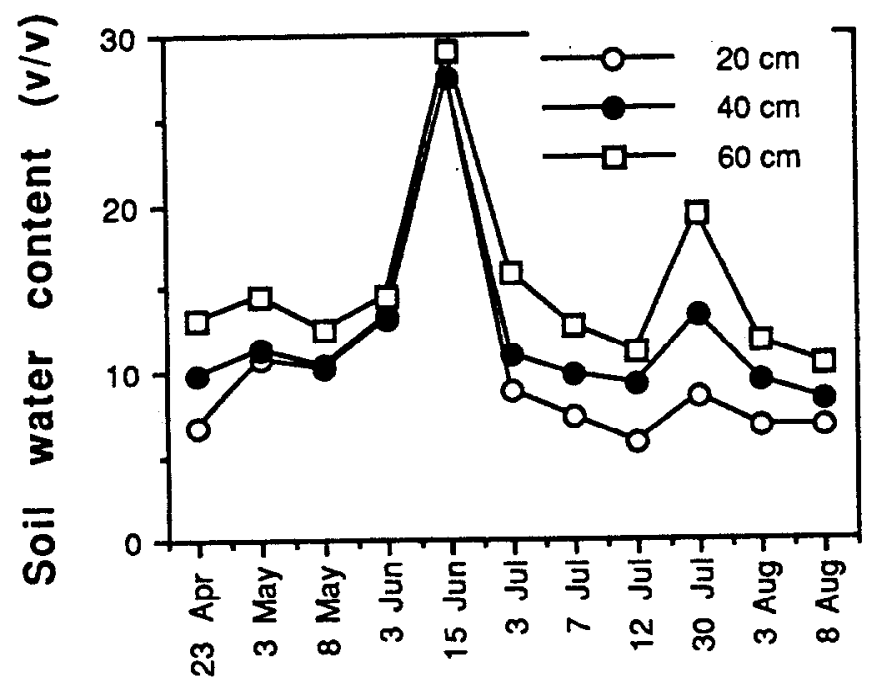

Fig. 2. Soil water content $\left(\mathrm{cm}^{3} \mathrm{~cm}^{-3}\right)$ at 3 soil depths measured with a TDR unit throughout the spring-summer growing season in the field. Each data point is an average of 4 replications. The standard errors of the mean are smaller than the symbols. Death of some broom snakeweed plants was noted during mid July when water content in the $20-\mathrm{cm}$ profile decreased to $0.065 \mathrm{~cm}^{3} \mathrm{~cm}^{-3}$. 
threshold soil water content at which broom snakeweed dies was very similar for the pot study and field obervations. This indicates that soil water content in the top 20 or $30 \mathrm{~cm}$ of the profile is the single most important factor determining mortality of the snakeweed plant and can be used in making decisions in snakeweed control programs.

In the severely and extremely stressed treatments, the plants were exposed to low soil water potentials for prolonged periods (late April to late June and mid July to September). There was some adjustment to the water deficit through reducing canopy development and decreasing stomatal conductance which (Wan et al. 1993b), therefore, could increase their endurance to some extent. In the field, however, plant death occurred in less than 10 days from a sudden moderate to severe stress (from 3 to 12 July, Fig. 2). Accelerated canopy development occurred in the wet month of June, and plants were not able to reduce the canopy area sufficiently in the subsequent drought period. In addition, because stomata were less responsive to severe soil drought (Wan et al. 1993b), transpirational water loss was relatively high, causing tissues dehydration and possible xylem embolism. Therefore, when the threshold water content is reached in the field the time frame for snakeweed die-off is fairly short (weeks instead of months) if the drought is not relieved by precipitation events.

In conclusion, soil water deficit significantly reduced root length and biomass of broom snakeweed. The root/shoot ratio remained relatively constant at soil water potential between -0.02 and -2 $\mathrm{MPa}$, but increased significantly $(p<0.05)$ at $-3.4 \mathrm{MPa}$. Carbon allocation within the shoot was more sensitive to soil water deficit than allocation between root and shoot. Broom snakeweed died at an average water content of $0.03 \mathrm{~g} \mathrm{~g}^{-1}$ in the top 20 - to $30-\mathrm{cm}$ of the soil profile on the sandy loam soil, which was equivalent to a soil water potential of $-7.5 \mathrm{MPa}$.

\section{Literature Cited}

Courtney, R.W. 1984. Influence of site characteristics and phenology on carbohydrate trends in broom snakeweed (Xanthocephalum sarothrae). M.S. thesis, Texas Tech Univ., Lubbock, Tex.

DePuit, E.J., and M.M. Caldwell. 1975. Stem and leaf gas exchange of two arid land shrubs. Amer. J. Bot. 62:954-961.

Fernandez, O.A., and M.M. Caldwell. 1975. Phenology and dynamics of root growth of three cool semi-desert shrubs under field conditions. $J$. Ecol. 63:703-714.

Hinckley, T.M., F. Duhme, A.R. Hinckley, and H. Richter. 1983. Drought relations of shrub species:assessment of the mechanisms of drought resistance. Oecologia 59:344-350.

Jones, H.G., and R.A. Sutherland. 1991. Stomatal control of xylem embolism. Plant Cell Environ. 14:607-612.

Morgan, J.M. 1984. Osmoregulation and water stress in higher plants. Annu. Rev. Plant Physiol. 35:299-319.

Nobel, P.S., and J. Sanderson. 1984. Rectifier-like activities of roots of two desert succulents. J. Exp. Bot. 35:727-37.

Osman, A., and R. Pieper. 1988. Growth of Gutierrezia sarothrae seedlings in the field. J. Range Manage. 41:92-93.

Sharp, R.E., and W.J. Davies. 1979. Solute regulation and growth by roots and shoots of water-stressed maize plants. Planta 147:43-49.

Sperry, J.S., and M.S. Tyree. 1990. Water-stress-induced xylem embolism in three species of conifers. Plant Cell Environ. 13:427-436.

Tyree, M.S., and J.S. Sperry. 1989. Vulnerability of the xylem to cavitation and embolism. Annu. Rev. Plant Physiol. Mol. Biol. 40:19-38.

Tyree, M.S., and F.W. Ewers. 1991. Tansley Rev. No. 34. The hydraulic architecture of trees and other woody plants. New Phytol. 119:345-360.

Wan, C., R.E. Sosebee, and B.L. McMichael. 1993a. Drought-induced changes in water relations in Gutierrezia sarothrae under field and greenhouse conditions. Environ. and Exp. Bot. 33:323-330

Wan, C., R.E. Sosebee, and B.L. McMichael. 1993b. Broom snakeweed responses to drought. I. Photosyntbesis, conductance, and water use efficiency. J. Range Manage. 46:355-359.

Zimmerman, M.H. 1983. Xylem structure and the ascent of sap. SpringerVerlag, New York. N.Y. 